\title{
"Brought up to Live Double Lives": Intelligence and Espionage as Literary and Philosophical Figures in Ciaran Carson's Exchange Place and For All We Know
}

\section{ABSTRACT}

The article examines the figure of the spy-alongside themes related to espionage-as employed in two books by the Northern Irish writer Ciaran Carson (1948-2019): the volume of poems For All We Know (2008) and the novel Exchange Place (2012). Carson's oeuvre is permeated with the Troubles and he has been hailed one of key writers to convey the experience of living in a modern surveillance state. His depiction of Belfast thematizes questions of terrorism, the insecurity and anxiety it causes in everyday life, as well as the unceasing games of appearances and the different ways of verifying or revising identities. In Carson's later work, however, these aspects acquire greater philosophical depth as the author uses the themes of doubles, spies, and makeshift identities to discuss writing itself, the construction of subjectivity, and the dialogic relationship with the other. Taking a cue from Paul Ricoeur's and Julia Kristeva's conceptions of “oneself as another," the article examines how Carson's spy-figures can be read as metaphors for processes of self-discovery and identity-formation, tied to the notion of "self-othering." Carson employs the figure of the spy-who juggles identities by "donning" different clothes or languages - to scrutinize how one ventures into the dangerous territory of writing, translation and love, as well as to reconsider notions of originality and self-mastery. Ultimately, Carson conceptualizes literature as specially marked by deceptions and metamorphoses, defining in these terms the human condition.

Keywords: surveillance, espionage, otherness, identity, translation. 


\section{INTRODUCTION}

The revelation that Julia Kristeva-a globally recognized philosopher and psychoanalyst-was registered by the Bulgarian secret police as a collaborator in the 1970s sparked a lot of controversy, eliciting commentaries ranging from condemnation to exoneration. However, when the dust settled and those taking the moral high ground finished expressing their disdain for French intellectual circles and their leftist politics it became possible to identify aspects of the issue that might not have been apparent at first glance. These certainly include larger questions regarding the credibility of bureaucratic records in totalitarian regimes and the production of subjectivity under conditions of far-reaching surveillance. Still, what continues to baffle and fascinate is the literary aspect of such cases, namely the role of fiction in shaping one's identity or, in fact, multiple identities.

Kristeva outright rejected the allegations, claiming that she had never been part of any secret service agency, and dismissing the revelations in the article "It's Just Not My Life" as an instance of fiction. It is certainly not the point here to assess the truthfulness of either Kristeva's account or the hefty dossier that was made available online. Anyone with even cursory knowledge about the intricacies of the "game of files" played in the former Eastern bloc would have to concur that these cases are difficult to disentangle and certainly cannot be resolved by applying simplified criteria. The release of such documents always entails a number of ethical issues, especially with regard to the credibility of accounts produced by the secret police and the susceptibility of these materials to becoming part of local power struggles. What this reveals is not a clear-cut reality populated by heroes and villains, but a vast apparatus of power infiltrating the society and colonizing the human psyche, occurring as it were "behind official history" (Seed 117) or in the unconscious.

The mental pressures entailed by living in a police state or one marked by extensive application of surveillance techniques-both social and industrial-have been scrutinized in the context of the Eastern bloc, but are not exclusive to this part of Europe. In fact, one of the more pertinent cases in the West is that of Northern Ireland, where the effects of sectarian violence and the efforts of the state apparatus to thwart it have imbued themselves deeply in the minds of people living there. Among the first-hand witnesses of these intense transformations was Ciaran Carson, a Belfastborn poet (1948-2019), who considers in his works some of the farreaching consequences of living under the shadow of violence. As a literary chronicler of the Troubles, he focused primarily on the transformative effect that violence-direct and indirect, verbal and physical, guerrilla and 
military — has had on the psyche of those living in Belfast during the three decades marked by conflict. Notably, however, Carson did not assume the duties of a reporter but used the Troubles as a springboard for broader considerations of identity, social bonds, and their relationship with literary fiction. Specifically, he would develop the idea that spying and surveillance reveal something very important about both the nature of writing and human subjectivity, namely that they are both dependent on the process of self-othering. Taking a cue from works by Julia Kristeva and Paul Ricoeur-Strangers to Ourselves and Oneself as Another, respectively-it can be argued that identity formation is an essentially narrative process of fictionalizing oneself. However, this process is not regarded as private; on the contrary, as Carson demonstrates in his literary works, narrative identity is a nexus of various centrifugal forces that set the self in motion, decentralizing it. From this perspective, we all lead double lives insofar as we are subjects under scrutiny, our identities dispersed in a vast network of social relations, state records and material objects, and simultaneously make our own espionage-like forays into the unknown by becoming others in literature, translation, and love.

\section{SPYCRAFT AS HUMAN CONDITION}

Before directly engaging with Carson's works, it is necessary to sketch a rough theoretical model of spycraft as an existential paradigm. As it emerges in the case of Kristeva, an archaeology of surveillance requires care since it provokes intense self-questioning. This has been aptly demonstrated by Katherine Verdery, who undertook the arduous task of reconstructing the social ramifications of living under the watchful eye of Romania's Securitate, beginning in 1973 when she first travelled there as a researcher and was subsequently suspected to be an American spy. Although this was not the case, it did not prevent the secret police from amassing a three-thousand-page dossier about her. "There's nothing like reading your secret police file," Verdery writes in the preface to My Life As a Spy, "to make you wonder who you really are" (xi). What appeared particularly striking to her was the unique angle of the narrative emerging from the dossier- "an alien position embodied in a logic different from anything you recognize” (xi). A distorting mirror or prism, the dossier would redefine the importance of specific events in her life and various aspects of her identity. In the end, as she has come to recognize, her virtual alter ago "Vera" would teach her a unique lesson: "these doubles," she acknowledges, "echo experiences all of us have" (294). Although the "real" Katherine would find "this multiplication of identities disconcerting," Vera 
actually "knew from the outset that Katherine was mistaken in her belief in a singular self with a stable, unique identity"; and to complicate things further, "she took pleasure in how life in Romania gradually subverted Katherine's perspective” (294).

Kristeva strikes a similar note when she addresses her experience of moving to France in the above response, denying that she was "strategically" playing officials in an attempt to tread a fine line between a Bulgarian past and a French future. However, as she openly admits, her actual position was in fact much less a political stand-off than an existential quandary regarding her perpetual foreignness, which she has referred to since as "my destiny." In this context she asks "Is it not the major condition of being able to think, which means thinking from another point of view, from the point of view of the other?" This question carries special significance when posed in the situation of being neither fully here nor there, and is further exacerbated by the fact that the issue turns out to be not only private but also public: political and involving surveillance. Such destabilization of identity would thus appear highly ambiguous-"a challenge and an opportunity," as Kristeva notes with psychoanalytic acumen-because it simultaneously enables thinking and undercuts it.

As Neal Ascherson observes in his review of Verdery's book, "the recent fuss about Julia Kristeva boils down to nothing much, although it has suited some to inflate it into a fearful scandal." However, what these stories do imply is that being a spy-wittingly or not-can be understood as expressive of modern identity, as developed at the intersection between the public and the private. Clive Bloom has identified these two axes as key coordinates of spy fiction, arguing that this genre "constantly veers towards a paranoid vision of 'violation by outside agencies' and 'violation of individual autonomy by internal agencies"' (qtd. in Seed 115; emphasis in the original). Even when divorced from its immediate context of intelligence and released from clichéd narratives of combating evil masterminds, spycraft proves to be an eloquent metaphor of the human condition. It reveals the multifarious and reflexive character of identity, as well as the vast machinery of identity-formation that surreptitiously permeates our minds, especially when augmented by new technologies. The productive character of espionage as metaphor consists in the way it demonstrates the broad distribution of identity, which is no longer a stable, self-contained kernel that one carries around in the privacy of an individual soul. Identity emerges rather as an intersection of the public and the private, truth and fiction, entailing constant effort to both secure the continuity of the self and embrace its inevitable change. This is further corroborated in psychology, where the concept of narrative identity is also argued to reveal that "any person's particular narrative identity is a co- 
authored, psychosocial construction, a joint product of the person .... and the culture" (McAdams 112), thereby destabilizing the notion of a stable and enclosed self.

Certainly, this can be both terrifying and liberating as it reveals two significant truths: first, to quote Colette's words recalled by Kristeva, that "to be born again ... has never been beyond my capabilities," and second, in the words of Ascherson, who concludes his meditation on the politics of secret dossiers by turning away from the Cold War and looking towards the cyber-age, arguing that "we had never walked alone" and only now "begin to see that we never will" insofar as we are "shadowed by invisible robots, by doppelgängers fitted together by algorithms."

Importantly, these two axes of identity are also the staple of literary works by Ciaran Carson. Although any such reductions are inherently limited, one of the crucial tensions identifiable in his oeuvre is the one between individual autonomy and outside agency. The two are usually cast in more concrete terms, for example as the relationship between orality and textuality and, more specifically, as the tension between two languages: Irish and English. As Clíona Ní Ríordáin aptly observes (1), Carson addresses his bilingual heritage by dedicating his 1989 volume of poems Belfast Confetti to his father in both Irish and English: "do m'athair, Liam Mac Carráin / to my father, William Carson" (Carson, Collected Poems 124; henceforth $C P$ ). According to the critic, this testifies to Carson's fundamentally bilingual, dual identity, although he would also embrace the fact that "an equilibrium between the two languages is impossible" due to linguistic, religious, social and political reasons (1). Indeed, this imbalance has enabled the poet to switch between the two languages to assume different perspectives and even disguise himself in language, using it as "a cloak in which one can wrap oneself to become Other" (1). As Ríordáin points out by invoking interviews with Carson, his bilingual upbringing made him acutely aware of the intimate differences between languages, the political import of speaking a specific idiom, and the fascination with otherness expressed by immersing oneself in a foreign speech that ultimately reveals something uncannily familiar. In the private dimension, Carson's parents apparently met during Irish classes, causing them to fall "in love with each other and the language" (qtd. in Ríordáin 2), which introduces a crucial link between affection and engagement with linguistic otherness. On the other hand, Ciaran Carson's very name-the first name Catholic Irish and the last name Ulster Protestant-embodies his "doubledealing," an "ambiguity" he has come to "relish" (qtd. in Ríordáin 2). Indeed, this nexus of problems introduces key themes that recur in his work and are organized around the theme of a "double agent" who inhabits the twilight zone of the "in-between," undertaking perilous excursions into 
foreignness, in terms of which Carson redefines questions of identity and the self, as well as the functions of literary fiction and translation. What he establishes in the course of such "intelligence operations" is an account of the self as inherently plural, polymorphic and multilingual, hence governed by the rules of fiction and mobilized by processes of translation in which every move is a step into the unknown of otherness and a betrayal of what formerly appeared to be the stable nucleus of a seemingly mastered self and mother tongue.

\section{CARSON'S CHRONICLE OF THE TROUBLES}

Before Carson developed these philosophical questions in his later works, the immediate impulse for considerations focusing on espionage and spycraft was the Troubles, a crucial influence on his life and poetry. In The Irish for No (1987), his first volume to directly address the situation in Northern Ireland, he meditates on the impact that the conflict has had on Belfast not only in terms of the physical violence that ripped the city and its social fabric apart, but also acknowledging the conflict's discursive dimension of "legislation, the media, and local stories along with virtual powers of surveillance technology" (Houen 270). If we hope to develop effective ways of coping and healing, Carson points out, it is crucial to ask how violence is mediated by fiction, technology and everyday practices. "By charting this type of dynamic," Houen claims, "Carson offers new ways of thinking about the Troubles in terms of the relation of violence to textuality" (272). In this sense, he makes language the stage of rampant conflict, diagnosing how the city and the self are unstitched and unravelled, while violence and suspicion ingrain themselves in the way we conceive of ourselves and other people. In doing this, Carson demonstrates what spy fiction fleshes out so well, namely how we "internalize security as a constant state of domestic and psychological surveillance" (Seed 124). In the oft-cited poem "Belfast Confetti," the exploded bomb ("an asterisk on the map") and shots fired ("hyphenated line") make it impossible to "complete a sentence in my head," with "the side streets blocked with stops and colons" (CP 93). Because "every move is punctuated," the poem concludes, a "fusillade of question marks" descends, undermining all coordinates and points of reference, leaving the speaking persona stunted and "polymorphically mute" (Kristeva, Strangers 16): "What is / my name? Where am I coming from? Where am I going?” Perplexed and traumatized witnesses to the Troubles are shown by Carson as living in a psychotic reality characterized by distrust and never-ending games of appearances. In "Last Orders," entering a bar and ordering drinks is fraught with 
suspicion, with awkwardly cast glances measuring up everyone, amounting to a "Russian roulette, since you never know for sure who's who, or what / You're walking into" (CP 154). "I, for instance," the speaker observes, "could be anybody... . See me, would I trust appearances?" (154; emphasis in the original). Just as the city's fabric is torn, while its inhabitants' minds are infected with what David Seed identified in William Burroughs's spyfiction prose as "surreal conspiracies before which no area of the self remains intact" (130), Carson responds by developing a "new urban poetics" that involves "creation of new maps, the formulation of new concepts of identity and place, and the relationship between them" (KennedyAndrews, "Ciaran Carson" 145). To piece such new maps together, Carson draws on images and ideas derived from the shadowy world of intelligence.

In the prose poem "Intelligence," he observes that everyone is "being watched through peep-holes, one-way mirrors, security cameras, talked about on walkie-talkies, car phones, Pye Pocketphones" (CP 184). This has become the condition of urban life, exacerbated by distrust and speculation induced by the Troubles. "Everyone is watching someone, everyone wants to know what's coming next," Carson notes, and as we are being constantly kept under the watchful eye of others and surveillance devices, the systems of observation stack up on top of each other, forming "panopticons within panopticons" (185). John Goodby refers to this dystopia as "an ultimate nightmare," with "the slightest slip of the tongue" potentially "provoking lethal displays of intolerance" and technological forms of control turning the city into a "prison made totally transparent, and accessible, to power" (78-79). This kind of oppression, however, can be countered, though not by replacing the "oppressor's map with your own mirror-image of it" (78), Goodby concurs, drawing inspiration from Michel de Certeau, but by building up resistance through investment in narratives "relying on walking, local observation, the intimate, ground-level view" (80). The mutability of both city and subjectivity is traumatizing but simultaneously suggests ways of defying and eluding the surveillance machine as "glitches and gremlins and bugs keep fouling-up, seething out from the hardware, the dense entangled circuitry of backstreets, backplanes" (CP 184). "Intelligence" concludes with an exercise in counter-mapping that acknowledges the volatility of the "demolition city," working through trauma and loss by recollecting and spinning stories. Father and son look down at the city from the Black Mountain, trying to discern their home in the distance, identifying Belfast's landmarks and "homing in through the terraces and corner shops and spires and urinals ... while my father tells me a story" (187). Surveillance is thus balanced in the act of reclaiming the city through an alternative cartography of imagination that revolves around 
change, surprise and wilful disorientation, ultimately facilitating a "recomposition" along the lines of "a utopian spatial politics" (Alexander 88). In order to counteract the "edgy paranoia" developed as the default reflex among citizens of Belfast—a "Twilight Zone" regulated by "Special Powers" (qtd. in Alexander 102) -it becomes necessary for Carson to embrace a stealth mode of self-othering. This is achieved by abandoning the desire to exercise complete self-mastery through specific techniques: losing oneself in the city, following the impulses of involuntary memory, foraying into foreign languages, writing, or otherwise moving into the shadowy world of the in-between and embracing its potential for developing forms of counter-intelligence. These themes are further explored in his later works, specifically in the poetry volume For All We Know (2008) and the novel Exchange Place (2012).

\section{FOR ALL WE KNOW}

The above trajectories, surfacing already in the context of the Troubles in the late eighties, converge in the most intricate fashion in Carson's volume of poetry For All We Know. The book is unique among his works due to its dialogic construction. Split into two parts containing mirroring poems under the same titles, it focuses on Nina and Gabriel, two lovers whose "affair unfolds in an atmosphere of constant surveillance, fear, and paranoia" (Kennedy-Andrews, "Carson, Heaney" 240). The redoubling of the poems makes interpretation invariably suspended between the two parts, never actually allowing one to resolve all the echoes and variations. As Kennedy-Andrews observes, the structure of the volume makes it impossible to treat any of the two parts as "the original"-in a way, the original is always already lost, leaving the reader only with the two lovers' mutual "mis-translations" as they are locked in their "double-lives" (240). Set against the backdrop of the Cold War, as well as utilizing an array of noir tropes, the book uses its intricate architecture to render the uncertainty and mistrust that mark the lives of spies. Part psychological thriller and part noir parody, the book makes its own "facts ... take on a metaphorical turn" (Delattre, "Forest" 13). A "hall of mirrors," as Carson himself called it, For All We Know "seemed to generate its own energy" when being written due to the multiplication and intertwining of motifs, as well as the ceaseless work of variation and recurrence ("For all I know" 22).

The book's polyphonic character is closely connected with the art of the fugue, which figures prominently the volume, a motto from Glenn Gould offering vital insight into this matter: "Fugue must 
perform its frequently stealthy work with continuously shifting melodic fragments that remain, in the 'tune' sense, perpetually unfinished" (CP 490). Obsessed with the irreducible multiplicity of meanings, Carson also explores another sense of the word "fugue," which can refer to a medical condition: a rare dissociative disorder that can cause amnesia accompanied by an urge to travel or wander off, even for longer periods, in extreme cases leading to the formation of another identity. The two meanings of "fugue" dovetail in Carson's book insofar as he makes the two lovers continually strangers to themselves and to each other"perpetually unfinished." Both of them bilingual, it appears they were "brought up to live double lives" ("On the Contrary," CP 542) and thus find it easier to slip in and out of specific roles and identities, always becoming somebody else by adopting certain turns of phrase, changing clothes, or wearing different perfume, in short: "self-transforming" (Alexander 138). At the same time, their "doubled progeny," as Baltasi put it, continuously "erodes their sense of coherent unity" and reveals it to be strictly "language-bound" (170-71).

The pair's dance is traced back to the second-hand clothes shop where they met, already from the start sizing each other up and probing their identities: "You're not from around here, I said. No, from elsewhere, you said. / As from another language, I might have said, but did not" ("Pas de Deux," CP 503). Their own fugue develops in a dialogic manner, "one side revolving the other's words for other meanings" (503), following an elaborate ballet that involves words, gestures, displays of affection and, importantly, clothes and other material objects to which we delegate our self-expression, e.g., watches. Their "double lives," as Alexander points out, concern not only their linguistic background but also their actions as they move between Belfast, Paris and Dresden, questioning themselves, each other and others in a world where no identity seems fixed and every encounter is rife with potential for duplicity and misrecognition (137). Carson captures, as he pointed it out himself, how Nina and Gabriel "wonder who they might be, what they are to each other, and how they remember each other" or-to put it differently-explores "the translations they make of each other" (qtd. in Moi and Larsen 85). The lovers learn that even though they have some power over how they appear before others, they are also defined by how others see them. Learning how to "renegotiate themselves"- as when staying "in another country" ("Redoubt," CP 498) - they also have to master the art of "putting yourself into someone else's shoes" in order to reclaim or invent "that which me might have been had we been born as another" ("Treaty," CP 497); in this way, it appears paramount "to encompass the other's territory" (497) if one wants to discover what they can still become. 
What Carson suggests is that fiction permeates our lives to a far greater degree than is usually acknowledged. The domain of language is oftentimes likened in the book to a forest, one that we enter to find out that "trees have ears and mouths that listen and respond / to every passerby" ("Before," CP 527). Alive and reciprocal, this forest is interrogating us, contributing to our self-formation. "What is it in us," Carson asks in "To," "that makes us / see another in another?" (CP 523). His answer seems to be literary fiction since it offers a way out of solipsism at the cost of accepting the fictive structure of self and memory. In order to think myself, I have to be able to engage in some kind of self-othering in the sense of developing a split within myself that opens a window onto another. For Carson, literature plays this role insofar as language structures the thirdperson self-narrative that keeps our myriad selves together. The poem "Zugzwang," which closes the first part, ends thus: "so I write these words to find out what will become of you, / whether you and I will be together in the future" (CP 537), while its counterpart from the second part concludes: "so I return to the question of those staggered repeats / as my memories of you recede into the future" (CP 587). In light of the above, Carson's writing project is an inquiry into how writing operates as a mode of discovering one's own past and shaping the future self. On the one hand, it offers a mode of retelling the past again and again, always slightly differently because " $[\mathrm{t}]$ he lie is memorized, the truth remembered" "The Shadow," CP 508), piecing the patchwork identity together to establish narrative continuity. On the other, it provides a tool for becoming and moving forward. Writing is posed here as a fundamental act of "gathering intelligence," which grants access to the past and the future, defining the basic parameters of human experience. Thus, one can only reiterate the claim that For All We Know indeed constitutes "an intelligence operation in the truest sense" (Starnino 161). In this sense, the book uses the theme of espionage to develop the idea that all thought and writing are inherently mediated through otherness. This in turn makes translation the paradigm of such encounters with foreignness, as suggested by Paul Ricoeur in On Translation, where linguistic pluralism and translation are situated at the heart of subjectivity as its precondition. Translation shares much with espionage, as Mark Polizzotti argues in Sympathy for the Traitor. A Translation Manifesto. "In some ways," he notes, "translation and spying are natural bedfellows: both involve double allegiances, parallel modes of expression," as well as the necessity to "jump, like a seasoned performer, from one role to another, one voice to another, one persona to another," making it impossible to presuppose unequivocal loyalty (33). Indeed, Carson's complex relationship with English hinges on excursions into the Irish of The Táin and Brian Merriman's Cuiirt An Mbeán Oiche, 
the Romanian of Stefan Agustin Doinas, the French of Jean Follain, Arthur Rimbaud, Charles Baudelaire and Stéphane Mallarmé, as well as the Italian of Dante. His writing project is largely driven by encounters with foreignness, which have enabled him to discover new potential in English itself, revitalizing its energies and harnessing them to his own poetic ends. A spy-writer who looks to other cultures and languages for inspiration, Carson kept changing his literary identity in the course of metamorphoses inspired by numerous translations, versions, adaptations and internalizations of foreign texts.

\section{EXCHANGE PLACE}

In the novel Exchange Place Carson plays with genre boundaries, further exploring popular "pulp noir" and turning it into a vehicle for his own philosophical musings on subjectivity, as well as reflections on the Troubles. Carson's non-hierarchical bricolage approach has made him a "doubleagent" or "sophisticated primitive" who moves freely between popular convention and philosophical discourse, defying conventions (Hancock 152). The book investigates double-talk, deception and spycraft as vehicles for observations about the nature of human subjectivity, using the theme of "stepping into someone else's shoes" as both a "learning process" and an "enquiry into being" (Carson, Exchange Place 62). Interpreting the dictum "Le style, c'est homme" as a philosophical statement (113), Carson embraces "self-othering"-which notably manifests in his trying on various vintage second-hand clothes - as "a kind of method writing" that facilitates living in a "parallel world" (27). In fact, to illustrate this, he develops his own multiverse theory, which is sketched in the book along the lines of a musical fugue: "a universe of infinite worlds and endlessly repeated variations, endlessly doubled lives" (43). Except that this is also something that plays out in the most common situations, forming the nucleus of sociality. The façade of the spy-novel underscores the right notes in order to display this more efficiently: "Eyes staring at one's back. Meeting of glances. We are others in the eyes of others. I am many John Kilfeathers" (128). As John Kilpatrick, the other protagonist whose path slowly converges with that of Kilfeather, reads from his notebook in the Rimbaudian chapter "Je Est un Autre": "in our walk through life we change... and are altered by the glance of others ... and our bodies are altered by those negotiations whether we know it or not" (142). As he concludes, "we are not one but many, we are the sum of all we are to others" (142). This implies-as Kristeva elaborates in Strangers to Ourselves, taking a cue from Freud's concept of the uncanny (regarding the immanence of the strange in the familiar)- 
that our own psychological depth is matched by what is external and inaccessible, dissolving any notion of a "solid" self (192). If in the end we are all "foreigners to ourselves" (170), then "the other is my own, proper unconscious" (183). This, she argues, also forms the ethical injunction to open up to otherness because closing it off would mean eliminating a vital part of ourselves, most notably foreclosing the potential to meaningfully engage with other people and their stories, ultimately thwarting selfdevelopment. Lastly, the dialogic relation between myself and the other is likened by Kristeva to a fugue, which never "solidifies" the other but acknowledges radical foreignness as the precondition of subjectivity (3).

The musical "fugere" or the endless, non-conclusive flight of the fugue is therefore rendered similar to the medical condition of fugue as "mad travel” (as Ian Hacking called it) because it dramatizes the radical character of becoming someone else, a process in which identity is destabilized, characterized by "negation of any notion of linear and intentional lived experience" (Baker 6). As Alan Gillis remarks in the context of Carson's novel $X+Y=K$ (an unpublished shadow version of Exchange Place), fugue in the medical sense provides access to "the matrix" defined by Carson as "a realm of traces in which 'any and all information about any person, place or thing might be obtained"' (255). This parapsychic dimension-itself the shadow or other of real-life surveillance-is presented in Exchange Place as "the Other Side," who are "in the business of knowing" and "look at everything" (174). Akin to the "Great Game" of spy fiction (Seed 119), this theme can suggests a vast network of interconnections, interdependencies and interrelations, forming a dense palimpsest of traces readable only if one develops the ability to assume different perspectives, yet impossible to grasp by any single actor. To glimpse this realm, the protagonist must visit the "Cave of Changes" and then step through a mirror, both of these tropes standing for self-transformation and self-othering.

Finally, the work of fugue can be also observed in terms of the book's composition. Full of "extracts from books, fictional or otherwise," as Carson explains in a meta-commentary (152), Exchange Place is in fact also a "montage" (Delattre, "Déjà vu" 158) that strategically deploys numerous quotations and foreign expressions, foregrounding insurmountable language differences. Moreover, all writers "mirror" others, Carson observes, "whether consciously or unconsciously" (152), which brings them closer to translators rather than self-sufficient, "original" and "natural" geniuses of the Romantic or post-Romantic vein. This serves as a commentary on the creative process itself, which is cast here as essentially relational and occurring at the crossroads of one's own words and those of others, using them to open windows that afford glimpses of a larger reality. 


\section{CONCLUSION}

Towards the end of Still Life, Carson's last poetry book, written and published in 2019 when he was terminally ill, he ponders Windows, a series of paintings by Basil Blackshaw. In the first part of the poem he notes that "to write about the windows or indeed around them" means attempting "not so much to delineate / As to allow a little leeway as to what they mean that must include the shifting memories" (57). In the last part of the poem it is revealed that Windows are important for him due to his memory of seeing them together with his wife Deirdre (61). In the collection's last poem, devoted to James Allen's The House with the Palm Trees, Carson concludes the ekphrastic series by using the painting to open a window onto a memory of a house he once lived in, ending the poem (as well as the volume) by referring to windows: "And I loved the big windows and whatever I could see through them, be it cloudy or clear, / And the way they trembled and thrilled to the sound of the world beyond" (73). This appears particularly ambiguous as we also learn from the book that these "trembles" could have been caused by a bomb going off at a nearby bar. The political and social context of the Troubles and the ensuing policing, including heavy surveillance, enforces itself here traumatically, but the ability to be affected-both in positive and negative terms-appears to depend on leaving that window open: sensitive to the larger reality and not boarded up out of fear.

If Carson is right to claim that every "human being is a story-telling machine, and the self is a centre of narrative gravity" (Exchange Place 161), we are all translators who try to make sense of the world by spinning stories that venture into foreign and sometimes dangerous territory. It is in this sense that Julia Kristeva tries to bring together the figures of foreigner, translator and writer in the essay "The Love of Another Language." Carson's own travels into the perilous realms of music, love, self-enquiry, political violence, state surveillance, foreign idioms and literatures, art forms, and various modes of writing, including genrebending, adaptation, translation and quotation, appear driven by what Kristeva calls "a lucid yet passionate love" for new languages, which offer "a pretext for rebirth: new identity, new hope" (241). Though he lived in Belfast all his life, Carson could be called, to invoke Kristeva, a "migrant writer" or "hybrid monster"- the kind who inhabits "the crossroads of languages," practicing a type of speech that acts as a vehicle for strangeness (244), which is both the task of writer (as translator and foreigner), as well as the "minimum and primary condition for being alive" (254). And although neither Carson nor Kristeva were real spies (for all we know), their work provides guidelines for perceiving this trade as expressive of 
human subjectivity, demonstrating its precarious plurality held together by fiction, and the dependence on the other for its constitution. Finally, they both indicate how surveillance has become an important aspect of identity production, gesturing towards the new, global systems of largescale data manipulation that encroach on our becomings today.

\section{Works Cited}

Alexander, Neal. Ciaran Carson. Space, Place, Writing. Liverpool UP, 2010. https://doi.org/10.2307/j.ctt5vjcgf

Ascherson, Neal. "Don't Imagine You're Smarter." Review of My Life as a Spy, by Katherine Verdery. London Review of Books, vol. 40, no. 14, 19 Jul. 2018, https://www.lrb.co.uk/the-paper/v40/n14/nealascherson/don-t-imagine-you-re-smarter, accessed 14 July 2021.

Baker, Timothy C. "Second Time Round: Fugal Memory in Ciaran Carson's For All We Know." Review of Irish Studies in Europe, vol. 1, no. 1, 2016, pp. 1-17. https://doi.org/10.32803/rise.2016.01.02

Baltasi, Michael. Review of For All We Know, by Ciaran Carson; Collected Poems, by Ciaran Carson. Chicago Review, vol. 55, no. 1, 2010, pp. 167-71.

Carson, Ciaran. Collected Poems. Gallery, 2008.

Carson, Ciaran. Exchange Place. Blackstaff, 2012.

Carson, Ciaran. "For all I know. Ciaran Carson in Conversation with Elmer Kennedy-Andrews.” Ciaran Carson. Critical Essays, edited by Elmer Kennedy-Andrews, Four Courts, 2009, pp. 13-27.

Carson, Ciaran. Still Life. Gallery, 2019.

Delattre, Elisabeth. "Exchange Place by Ciaran Carson or a Sense of Déja vu.” Studi irlandesi. A Journal of Irish Studies, vol. 5, 2015, pp. 157-69. https://doi.org/10.13128/SIJIS-2239-3978-16342

Delattre, Elisabeth. “Through the Forest of Language': For All We Know by Ciaran Carson." Estudios Irlandeses, vol. 7, 2012, pp. 10-18. https:// doi.org/10.24162/EI2012-1531

Gillis, Alan. "Acoustic Perfume." Ciaran Carson. Critical Essays, edited by Elmer Kennedy-Andrews, Four Courts, 2009, pp. 254-74.

Goodby, John. "Walking in the city': Space, Narrative and Surveillance in The Irish for No and Belfast Confetti." Ciaran Carson. Critical Essays, edited by Elmer Kennedy-Andrews, Four Courts, 2009, pp. 66-85.

Hancock, Tim. "Ciaran Carson: The Spy in the Superior Turret." Ciaran Carson. Critical Essays, edited by Elmer Kennedy-Andrews, Four Courts, 2009, pp. 142-60.

Houen, Alex. Terrorism and Modern Literature. From Joseph Conrad to Ciaran Carson. Oxford UP, 2005. 
Kennedy-Andrews, Elmer. "Carson, Heaney, and the Art of Getting Lost." Ciaran Carson. Critical Essays, edited by Elmer Kennedy-Andrews, Four Courts, 2009, pp. 227-53.

Kennedy-Andrews, Elmer. "Ciaran Carson: The New Urban Poetics." Shadows of the Gunmen. Violence and Culture in Modern Ireland, edited by Danine Farquharson and Sean Farrell, Cork UP, 2007, pp. 142-64. Kristeva, Julia. "It's Just Not My Life-Julia Kristeva Responds." Translated by Patsy Baudoin. Los Angeles Review of Books Blog, 11 Jan. 2018. https://blog.lareviewofbooks.org/essays/just-life-juliakristeva-responds/, accessed 14 July 2021.

Kristeva, Julia. Strangers to Ourselves. Translated by Leon S. Roudiez. Columbia UP, 1991.

Kristeva, Julia. "The Love of Another Language." Intimate Revolt. The Powers and Limits of Psychoanalysis. Volume 2, translated by Jeanine Herman, Columbia UP, 2002, pp. 240-54.

McAdams, Dan P. "Narrative Identity." Handbook of Identity Theory and Research. Volume I, edited by Seth J. Schwartz, Koen Luyckx and Vivian L. Vignoles, Springer, 2011, pp. 99-115. https://doi.org/10.1007/9781-4419-7988-9 5

Moi, Ruben, and Annelise Brox Larsen. "'Second Time Round': Recent Northern Irish History in For All We Know and Ciaran Carson's Written Arts." Nordic Journal of English Studies, vol. 13, no. 2, 2014, pp. 80-95. https://doi.org/10.35360/njes.305

Polizzotti, Mark. Sympathy for the Traitor. A Translation Manifesto. MIT, 2018. https://doi.org/10.7551/mitpress/10744.001.0001

Ricoeur, Paul. Oneself as Another. Translated by Kathleen Blarney. Chicago UP, 1992.

Ricoeur, Paul. On Translation. Translated by Eileen Brennan. Routledge, 2006.

Ríordáin, Clíona Ní. "Ciaran Carson and the Equilibrium of Language(s)." Études de stylistique anglaise, vol. 14, 2019, pp. 1-12. https://doi. org/10.4000/esa.3525

Seed, David. "Spy Fiction." The Cambridge Companion to Crime Fiction, edited by Martin Priestman, Cambridge UP, 2003, pp. 115-34. https:// doi.org/10.1017/CCOL0521803993.008

Starnino, Carmine. Review of For All We Know, by Ciaran Carson. Poetry, vol. 193, no. 2, Nov. 2008, pp. 159-61, www.jstor.org/stable/20608364, accessed 14 July 2021.

Verdery, Katherine. My Life as a Spy. Investigations in a Secret Police File. Duke UP, 2018. https://doi.org/10.1215/9780822371908 
Grzegorz Czemiel is Assistant Professor in the Institute of Modern Languages at the Maria Curie-Skłodowska University in Lublin, Poland. He received his PhD from the University of Warsaw on the basis of a dissertation on Ciaran Carson's poetry (Limits of Orality and Textuality in Ciaran Carson's Poetry, Peter Lang, 2014). His academic interests include contemporary poetry, speculative and weird fiction, translation studies, as well as literary theory and philosophy, especially ecopoetics and speculative realism. Currently, he is developing the concept of "speculative cartography," involving poetry as a geophilosophical mode of making cognitive maps. He also translates academic books and articles. https://orcid.org/0000-0002-1518-2834

grzegorz.czemiel@poczta.umcs.lublin.pl 